\title{
MEKHANOCHEMICAL METHOD FOR ACTIVATION OF VANADIUM OXIDE (V)
}

\author{
V. Fomenko, O. Kronikovsky \\ National University of Food Technologies
}

\begin{tabular}{l}
\multicolumn{1}{c}{ Key words: } \\
Ball milling \\
Nanotubes \\
Intercalation \\
Structure \\
Vanadium oxide \\
\hline \multicolumn{1}{c}{ Article history: } \\
Received 12.07.2018 \\
Received in revised form \\
03.08.2018 \\
Accepted 22.08.2018 \\
\hline Corresponding author: \\
V. Fomenko \\
E-mail: \\
npnuht@ukr.net
\end{tabular}

\section{ABSTRACT}

Oxide materials that contain an oxide nanopipes of $(\mathrm{OH})$ are characterized by heterogeneity of nanoparticles except $(\mathrm{OH})$ contain other nanosize units, such as ribbons, filaments and others. Materials on the basis of $(\mathrm{OH})$ are got mainly by the hydrolysis of connections of metals at temperatures to $180^{\circ} \mathrm{C}$. Further researches in the field of the synthesis of pseudounidimensional (1D) structures are related to the necessity of the detailed study of mechanisms of origin and height of these structures. In addition, such researches have an aim to create new more accessible methods of forming homogeneous nanoparticles of mproducts. One of such objects there is vanadium oxide $\left(\mathrm{V}_{2} \mathrm{O}_{5}\right)$, that is used as a selective catalyst and semiconductor in ceramics for transistors, and also as material of lithium accumulators. To this day oxide of vanadium of tubular nanomorphology (H-VO) of ) was got as a result of long hydrothermal (to 10 twenty-four hours) treatment $\left(\sim 180^{\circ} \mathrm{C}\right)$ of water solutions of such connections as $\mathrm{V}_{2} \mathrm{O}_{5}$, $\mathrm{VOCl}_{3}, \mathrm{HVO}_{3}$ in a presence $(\mathrm{KH})$ as templant (inert substance that is responsible only for forming form and size of nanoparticles of product), and also with the obligatory presence of ammonia. The results of studying the microstructure of vanadium oxide formed during grinding of standart sample of $\mathrm{V}_{2} \mathrm{O}_{5}$ in a planetary mill in the presence of ethanol are presented. Received samples were studied by methods of IR specktroscopy and XRD analysis. The morphology is investigated by methods of scanning and transmission electron microscopy, and the microstructure - by method of high-resolution transmission electron microscopy. The length of nanotubes is comparable with that of crystals of an initial $\mathrm{V}_{2} \mathrm{O}_{5}$ powder. The formation of $\mathrm{V}$-containing monolayers, scrolling of which leads to the formation of $\mathrm{V}_{2} \mathrm{O}_{5}$ nanotubes, most likely proceeds due to a plastic deformation of the $\mathrm{V}_{2} \mathrm{O}_{5}$ crystal lattice. The intercalation of alcohol molecules into the interplanar space of the $\mathrm{V}_{2} \mathrm{O}_{5}$ crystall causes deformation of crystals with formation of nanosized cleavage subjects which size and morphology can be considered as nanochemical.

DOI: $10.24263 / 2225-2924-2018-24-4-27$ 


\section{МЕХАНОХІМІЧНИЙ СПОСІБ АКТИВАЦІЇ ВАНАДІЙ ОКСИДУ (V)}

\section{В.В. Фоменко, О.I. Кроніковський \\ Національний університет харчових технологій}

Оксидні матеріали, які містять оксидні нанотрубки (ОН), характеризуються великою неоднорідністю наночастинок, оскільки, крім (ОН), містять інші нанорозмірні структурні одиниці, такі як стрічки, нитки тощо. Матеріали на основі (OH) отримують переважно гідролізом сполук металів при температурах до $180^{\circ} \mathrm{C}$. Подальші дослідження у сфері синтезу псевдоодномірних (1D) структур пов'язані з необхідністю детального вивчення механізмів зародження та росту циих структур. Крім того, такі дослідження мають за мету створити нові, більш доступні методи формування однорідних за формою наночастинок продуктів. Одним з таких об'єктів є ванадію оксид $V_{2} \mathrm{O}_{5}$, який здавна використовується як селективний каталізатор та напівпровідник у кераміці для транзисторів, а також як матеріал літієвих акумуляторів.

Донині оксид ванадію трубчастої наноморфологї (Н-VO) був отриманий в результаті довгої гідротермальної (до 10 діб) обробки ( 180 ${ }^{\circ}$ ) водних розчинів таких сполук, як $\mathrm{V}_{2} \mathrm{O}_{5}, \mathrm{VOCl}_{3}, \mathrm{HVO}_{3}$ за наявності (KH) як темпланта (інертної речовини, яка відповідає тільки за формування форми та розміру наночастинок продукту), а також з обов'язковим додаванням аміаку. Наведено результати дослідження зміни структури ванадій оксиду, отриманого під час розмолу стандартного зразка иъього оксиду у планетарному млині за участі етанолу. Отримані зразки досліджені методами інфрачервоної спектроскопї та ренгенофазового аналізу, також оцінена питома поверхня методом хроматографії. Методами скануючої та трансмісійної електронної мікроскопї показано, щчо в ході розмолу вихідна структура оксиду руйнується з утворенням нанотрубок, довжина яких аналогічна довжині складових вихідного ванадій оксиду. Утворення ванадійвмістних мономарів, які лежать в основі структури нанотрубок, найбільш імовірно відбувається за рахунок деформачії вихідної кристалічної структури ванадій оксиду. Інтеркаляція молекул етанол в міжплощинний простір кристалів оксиду спричиняє деформацію кристалів, з утворенням нанорозмірних об'єктів, розмір $і$ морфологія яких можуть бути означені як нанохімічні.

Ключові слова: ванадію оксид (V), активація, шаровий млин, інтеркаляція, структура, нанотрубки.

Постановка проблеми. 3 моменту отримання та описання матеріалів, побудованих з так званих наночастинок, які мали незвиклі фізико-хімічні властивості, потік досліджень таких матеріалів та способів їх отримання досяг лавиноподібної форми, яким залишається і досі. Перші дослідження на цю тему стосувалися отримання наноформ карбону $(\mathrm{KH})$, але надалі фронт досліджень розширився на інші технологічно важливі речовини: метали, 
інтерметаліди, оксиди, сульфіди, силіциди тощо. На основі цих досліджень була сформована картина галузей використання цих наноматеріалів i досягнутий великий прогрес у багатьох царинах науки й технологій [1]. Синтез вищезазначених сполук відбувається при підвищеній температурі за участі пароподібних компонентів і регульованому режимі. Однак оксидні матеріали, які містять оксидні нанотрубки $(\mathrm{OH})$, характеризуються великою неоднорідністю наночастинок, оскільки крім $(\mathrm{OH})$ містять інші нанорозмірні структурні одиниці, такі як стрічки, нитки тощо.

Аналіз останніх досліджень і публікацій. Матеріали на основі $(\mathrm{OH})$ отримують переважно гідролізом сполук металів при температурах до $180^{\circ} \mathrm{C}$. Подальші дослідження у сфері синтезу псевдоодномірних (1D) структур пов'язані 3 необхідністю детального вивчення механізмів зародження та росту цих структур [2]. Крім того, такі дослідження мають за мету створити нові більш доступні методи формування однорідних за формою наночастинок продуктів. Очевидно, що перш за все об'єктами таких досліджень стають вже широко використовувані в технологіях об'єкти з метою покращення їхніх властивостей.

Одним 3 таких об'єктів є ванадію оксид $\mathrm{V}_{2} \mathrm{O}_{5}$, який здавна використовується як селективний каталізатор та напівпровідник у кераміці для транзисторів, а також як матеріал літієвих акумуляторів.

Донині оксид ванадію трубчастої наноморфології (H-VO) був отриманий в результаті довгої гідротермальної (до 10 діб) обробки $\left(\sim 180^{\circ} \mathrm{C}\right)$ водних розчинів таких сполук як $\mathrm{V}_{2} 0_{5}, \mathrm{VOCl}_{3}, \mathrm{HVO}_{3}$ за наявності (КН) як темпланта (інертної речовини, яка відповідає тільки за формування форми та розміру наночастинок продукту), а також з обов'язкововим додаванням аміаку або амінів як молекулярних темплантів, які визначають структуру синтезованих наночастинок [3-8]

Подальша обробка VO-H від темплантів має різний механізм дії. Якщо (КН) темпланти повністю видаляються при прожарюванні вихідного продукту при $700^{\circ} \mathrm{C}$ на повітрі, то молекулярні темпланти інтеркалюються в шари ванадій-оксиген істотно (в 4-9 разів) збільшуючи міжплощині відстані до $1,7-3,8$ нм (залежно від типу аміну). Довжина H-VO сягає до 15мкм при зовнішньому діаметрі $15-150$ нм та внутрішньому $5-50$ нм. Хімічний склад таких нанотрубок описаний як $\operatorname{VOx}\left(\mathrm{C}_{\mathrm{n}} \mathrm{H}_{2 \mathrm{n}}+4 \mathrm{~N}\right) y$, де $0,28<x<2,47 ; 0,25<y<0,3$ (звичайно, що це занадто приблизна формула, яка відображає лише брутто склад матеріалу, а не атомну структуру трубки)

$\mathrm{H}-\mathrm{VO}$ трубки принципово відрізняються від КН трубок не тільки зростанням (порівняно із шарами $\mathrm{V}_{2} \mathrm{O}_{5}$ ) міжплощинних відстаней, але й формою частинок: якщо для КН це закриті циліндри, то H-VO утворюються у вигляді спіралевидних шарів, кінці яких відкриті. Кількість таких шарів і товщина стінок $\mathrm{H}-\mathrm{VO}$ визначається природою темпланта аміна.

Також було встановлено [9], що розміри та форма H-VO трубок істотно залежать від $\mathrm{pH}$ середовища при гідротермальному синтезі за наявності аміаку й аміну.

3 наведених вище даних видно, що чисті, неінтерколіровані трубки H-VO не були отримані. Тому питання отримання неінтерколірованих H-VO трубок на основі $\mathrm{V}_{2} \mathrm{O}_{5} \epsilon$ цікавим для дослідження їхніх властивостей. Це базувалося 
на факті, що були отримані незвичайні результати з істотного підвищення каталітичної активності оксиду ванадію при їх механоактивації у таких дисперсних середовищах, як етанол та вода [10;11]. При цьому були висунуті гіпотези, що механоактивація $\mathrm{V}_{2} \mathrm{O}_{5}$ в етанолі обумовлює високу каталітичну активність продукта за рахунок деформації кристалічної гратки при входженні в міжшаровий простір $\mathrm{V}_{2} \mathrm{O}_{5}$ молекул етанола. У випадку механоактивації $\mathrm{V}_{2} \mathrm{O}_{5} 3$ водою підвищення каталітичної активності пов'язувалося 3 утворенням на поверхні $\mathrm{V}_{2} \mathrm{O}_{5}$ поліванадатних кислот $\left(\mathrm{V}_{6} \mathrm{O}_{17}\right.$ або $\left.\mathrm{V}_{6} \mathrm{O}_{16}\right)$.

Мета дослідження: дослідити утворення нанатрубок $\mathrm{H}-\mathrm{VO} 3$ діаметром 150 - 250 нм в умовах більш «м'якого» способу механохімічного диспергування кристалів оксиду ванадію.

Викладення основних результатів дослідження. Як об'єкт дослідження був взятий стандартний порошок $\mathrm{V}_{2} \mathrm{O}_{5}$ (ч.д.а.), який підлягав механохімічній обробці у високошвидкісному планетарному млині зі сталевими барабанами та кулями. Змінні параметри експерименту - маса наважки оксиду ванадію, об'єм дисперсного середовища (етанолу або води ) та час механобробки (530 звилин). Кожен механоактивований зразок досліджувався за допомогою скануючого мікроскопа ( Hitachis-4000; $5 \mathrm{kV}$ ) та трансмісійного мікроскопа (Philips CM200 LaB6 i 200 kV), IЧ спектроскопа (Specord 75 IR) в межах $400-4000 \mathrm{~cm}^{-1}$, а також дифрактометра (ДРОН-УМ1; Cu Ka). Питому поверхню зразків визначали методом десорбції азоту на приладі Газохром-1.

3 аналізу зображень зразків, отриманих у скануючому мікроскопі (вихідний зразок $\mathrm{V}_{2} \mathrm{O}_{5}$; зразок механоактивований на повітрі протягом 10 хвилин; дисперговані відповідно у воді та етанолі протягом 10 хвилин і нарешті-дисперговані відповідно у воді та етанолі протягом 30 хвилин ) дає можливість зробити певні узагальнення. Так, у початковий період диспергування в етанолі кристали $\mathrm{V}_{2} \mathrm{O}_{5}$ руйнуються у формі частинок асиметричної форми розміром $0,2 * 2$ мкм. Про це також свідчить істотне зростання питомої поверхні зразка (приблизно у 1,5 раза). Диспергування у воді показує, що порівняно зі зразками в етанолі дисперговані зразки мають більші розміри та іншу форму, більше наближену до сферичної з діаметром до 4-5 мкм, що може свідчити не тільки про руйнування структурних одиниць вихідного $\mathrm{V}_{2} \mathrm{O}_{5}$, а й про утворення на поверхні кристалів $\mathrm{V}_{2} \mathrm{O}_{5}$ поліванадат -іонів аморфного характеру. $3 \mathrm{i}$ зростанням часу диспергування вміст більш дрібних пластинок (50-100 нм) істотно зростає і нарешті при максимальному часі помолу були отримані зразки, в яких поряд 3 пластинками виникають анізотропні частинки у формі довгих (більше 400 нм) та тонких (50 нм) стрижнів, які в об'ємі зразка розміщенні відносно однорідно. Ці частинки можна було спостерігати і у знімках, отриманих за допомогою трансмісійної електронної спектроскопії ТЕМ. 3 TEM зображень можна зробити висновки, що прутки являють собою нанотрубки. Можна припустити, що ці трубки формуються за рахунок «скручування» ванадій-оксигенного йоношару вихідного зразка $\mathrm{V}_{2} \mathrm{O}_{5}$. Довжина цих трубок не перевищує довжину кристалів вихідного $\mathrm{V}_{2} \mathrm{O}_{5}$. Скручування V-O шару відбувається немов би на тонкому стрижні (5нм), який помітно відображається по всій довжині нанотрубки. 
Міжплощинні відстані в нанотрубках відповідають близько 0,81 нм, що приблизно вдвічі більші ніж міжплощинні відстані у вихідному V205, але вдвічі менші ніж у зразках, отриманих за участі амінів, де відбувається інтеркаляція амінів у структуру при отриманні H-VO трубок. Це свідчить, про те що механообробка 3 етанолом дозволяс отримати іншу структуру, ніж у гідротермальному синтезі за участі темплантів амінів.

Інтеркалірування молекул етанолу в міжплощинні шари V-O приводить до більш легкого руйнування площин та утворення нових V-O шарів, де октаедрична координація атому ванадію змінюється на іншу, що може привести до деформації зв'язків V-O.

314 спектрів вихідного (0 хвилин) та механоактивованих (10, 20, 30 хв) зразків очевидно, що форма та інтенсивність лінії, характерної для поглинання $\mathrm{V}=\mathrm{O}$ зв'язка істотно змінюється в часі, що відповідає утворенню нанотрубок. Ця лінія розщеплюється на дві: більш інтенсивну при $1020 \mathrm{~cm}^{-1}$ та менш інтенсивну при $1000 \mathrm{~cm}^{-1}$. Лінія $820 \mathrm{~cm}^{-1}$, яка відповідає коливанням зв'язків V-O-V можуть свідчити про деформації, пов'язані зі зміною координації атомів ванадію.

Аналіз дифрактограм зразків дає можливість припустити, що деформація та руйнування вихідних кристалів V205 відбувається переважно по кристалографічних площинах (010) та (110). Найбільш істотно зменшується інтенсивність рефлекса дифрактограми, що відповідає площинам (110) в початковий момент диспергування. Тільки в етанолі деформація кристалів V205 у пасі веде переважно до зміни інтенсивності рефлекса (010), а не рефлекса (110), яка спостерігається для зразків, диспергованих у воді. В цій ситуації можна було припустити, що молекули етанолу інтеркалюють у міжплощинний простір V205. Це, у свою чергу, веде до послаблення зв'язків між сусідніми V-O шарами (010) та утворення тонких пластинок, які надалі, як показали електронномікроскопічні знімки, скручуються у нанотрубки.

\section{Висновки}

Отже, за результатами проведеного дослідження можна зробити висновок, що нанотрубки оксиду ванадію H-VO можна отримати не тільки в умовах жорсткого та довгого процесу гідротермального синтезу, але й в умовах більш «м'якого» способу механохімічного диспергування кристалів оксиду ванадію. Це й не дивно, бо механічна енергія, яка виділяється під час зіткнення сталевих куль і зразка оксиду, не менша, ніж енергія, що отримується від нагріву та реакції під час гідротермального синтезу.

\section{Література}

1. Захаров Г.С. Нанотрубки и родственные наноструктуры оксидов d-металлов / Г.С. Захаров, В.Л. Волков, В.В. Ивановская, А.Л. Ивановский // Успехи химии. — 2005. 7. - C $651-685$.

2. Patzke G.R., Krumeich F., Nesper R. Oxide Nanotubes and Nanorobs- Anisotropic Modules for a Future Nanotechnology // Angew. Chem. Int. Ed. - 2002. — 41. — P. 2446-2461.

3. Ajayan P.M., Stephan O., Redlich P., Colliex C. Carbon nanotubes as removable templates for metal oxide nanocomposites and nanostructures //Nature. - 1995. - 375. - P. 564. 
4. Muhr H.J., Krumeich F., Schonholzer U.P. et al. Vanadium Oxide Nanotubes. A New Flexible Vanadate Nanophase // Adv.mater. — 2000. - 12. - P. 231-236.

5. Xing Chen, Xiaoming Sun, Yadong Li. Self-Assembling vanadium oxide nanotubes by organic molecular templates // Inorg. Chem. - 2002. — 47. - P. 4524 4530.

6. Chandrappa G.T., Steunou N., Cassaignon S. et. al. Hydrothermal synthesis of vanadium oxide nanotubes from V2O5 gels // Cat Today. — 2003. - 78. — P. 85-89.

7. Wen Chen, Junfeng Peng, Liqiang Mai et al. Syntesis of vanadium oxide nanotubes from V2O5 sols // Material Lett. — 2004. - 58. - P. 2275-2278.

8. Krumeich F., Muhr H.J., Niederberger M. et al. The Cross-Sectional Structure of Vanadium Oxide Nanotubes Studied by Transmission Electron Microscopy and Electron Spectroscopic Imaging // Mater.Res. Soc.Symp. Proc. — 2000. — 581. — P. 393 - 398.

9. Pillai K.S., Krumeich., Muhr H.J. et al. The fi.rst oxide nanotubes with alternating interlayer distances // Solid StateI Ionics. - 2001. - 141-142. - P. 185-190.

10. Харламов А.И. Новый способ получения углеродных нанотрубок / А.И. Харламов, Н.В. Кириллова, А.А. Харламова // Теорет. и експер. химия. - 2002. - 6. - С. 347-352.

11. Ayub I., Su D., Willinger M. et al. Tribomechanical modification of Bi promoted vanadiy phosphate systems 1: An improved insight into structure-function relationship // Phys.Chem. 2003. - 5. - P. 970-978. 